\title{
Catherine Cole
}

\section{Henry James, Affect and the Writer/Researcher in the Academy}

In this paper I am going to examine the role of the fiction writer/academic in university writing programs, especially the way in which they wear numerous research hats. Multi-skilled in every sense of the word, they range over university research restlessly - research for a novel one day, pedagogical research the next, time snatched, if they're lucky, to pursue their 'formal' research projects, to apply for funding not just from the ARC but from the Literature Board and other community funds available to writers. They find the time to give conference papers and meet other researchers in their fields. While researchers in other disciplines such as science might say this is how it is in the academy today, especially in relation to expected research outcomes, the researcher in a writing program, I would argue, often enters research in a more complex and diverse manner, doffing one hat to replace it with another - sometimes deliberately crossing over into different research styles and genres, sometimes forgetting which hat they're actually wearing.

I'm sure this range of activities is perplexing to academic research funding agencies such as the ARC or traditional university grants schemes that expect writer/academics to be experts in a given field. Jacks- and Jills-ofall-trades when it comes to research and writing, their multi-skilledness and publication lists do them no favours with some of the people who read their grant applications. The questions always hover: 'Should I write refereed articles or short stories? Reviews or essays? A novel or an academic monograph?' Was it Scorsese or Coppola who said, 'one for Hollywood, one for me'? It is an approach all writers might apply to questions about their research and creative choices as they navigate their roles in the academy.

Despite these research conundrums, one of the joys of working in a university writing program is that creative work is valued and encouraged; that is why fiction writers are employed to teach fiction and why students seek them out. Multi-skilled, they can speak to students of texts and theory as well as their own writing practices and their experiences in the industry. Students see their teachers in their academic roles, delivering workshops and lectures, or outside the university at writers' festivals and bookshops promoting their fiction.

One of the most important skills these teachers bring to their academic writing is their ability to apply fictional techniques to their nonfictional work. For any writer the ability to capture the emotional atmosphere or affect of a piece is an important first step in writing, though academic 
writers might argue that this isn't or shouldn't be a consideration in researched nonfiction. I would beg to differ, citing Henry James, and his short story 'The Real Thing'.

James wrote a commentary about the way in which the story came to him from his friend George Du Maurier who had been visited by an old couple who wanted to supplement their income by posing as artist's models. James listened avidly to his friend's story, doing what writers do, turning the people into characters and investing them with a vivid life. Afterwards he was to write, 'I was struck by the pathos, the oddity, and typicalness of the situation - the little tragedy of good looking, simple-folk who had been all their lives stupid and well-dressed, living on a fixed income, at country houses, watering places, and clubs, like so many others of their class in England, and were now utterably unable to do anything' (James 1984: 1233).

What is of particular interest to me in the anecdote is the way in which James used his material. He could have written it as heard, but he was interested in something much more complex. 'It must be an idea - it can't be a story in the vulgar sense of the word', he decided. 'It must be a picture, it must illustrate something, God knows that's enough. ... One must put a little action - not a stupid, mechanical, arbitrary action, but something of the real essence of the subject' (James 1984: 1234).

Initially, James toyed with the idea of making things up about his characters, giving them dramatic or sordid histories or secrets, but decided against it. What he really wanted to represent was 'the baffled, ineffectual, incompetent character'. The consummate observer, he went on to create a narrative of great power from this little genesis, and the process he used, the way in which he explored the emotional core of the idea, offers insights into just how he pulled it off.

'Introduce a complication,' James said (which in James' case was a contrasting servant girl, with aspirations to the gentility his hard-up wouldbe models display). Her dialogue, with its Eliza Doolittle mispronunciations - lydy (lady), plise (please) - further highlights the pathos of the situation and its irony. 'The characters must be juxtaposed with the person who is paying them - and this transaction should cause amazement in the subjects.' James also wanted to capture the confusion felt by the couple at discovering that people who were once 'inferior' seemed to manage so well in the world.

James obviously enjoyed getting it right, and in the process he asked himself a lot of questions, the most interesting in relation to this paper: how does a writer sustain the idea behind a story such as this? $\mathrm{He}$ answered his own question: by 'being succinct, making it a short pulse or rhythm, a gem of bright, quick, vivid form.' James was determined to use his material artistically, and in so doing he played with the truth. $\mathrm{He}$ changed his characters' ages to make their plight more pathetic and to serve his narrative better. The result may have been a story about human frailty and disillusion but it was born of a very determined process of appropriating and subverting people's true stories.

While James was a fiction writer, his techniques have much to recommend them - particularly the way in which he explored the emotional affect or atmosphere of the piece, and how he did this through a predatory examination of his subjects. There is much to learn from his technique, not least the ways in which writers impose on or remove themselves from the 
narrative. Writing in the academy has a long history of excising the 'I' from writing. It is driven by its insistence on gravitas and 'truth', its ethics and permissions, but I also would argue that any writing relies as much on James' exploration of the 'felt' or the remembered as it does the researched and 'factual'. This process of collection by sifting and deduction is something we all do, and it always reminds me of TS Eliot's line from 'The Love Song of J Alfred Prufrock' that seems to exemplify the inevitable frustrations of writing: that is not it at all, That is not what I meant, at all.

These words express the longing writers often feel as they ask questions, piecing together feelings and images, jigsaw-like, their subjects resisting, arguing, forcing them to interpret in a kind of exquisite agony. The whole process is both unstable and inconsistent - and capturing the inconsistency becomes as vital as capturing the veracity.

I have experienced this frustration in my own research and writing about Vietnam, its history and its writers. I have used my research in fiction and nonfiction and, in both, Vietnam has lent itself very easily to this kind of exploration. My interest in the country is a long-standing one - as a baby boomer child who 'discovered' Vietnam through a war, Vietnam dogged my teenage years and my adulthood. It took shape through conscription, moratorium marches, massacres and refugees. It has had a profound effect, not just on me as an individual, of course, but on Australia's sense of itself. We hear it mentioned still in warning words about Iraq. Vietnam, a country forever synonymous with a foolish and destructive war.

The most significant concern for me has been how to capture the polyphonic narrative that resulted from such a war and how best to research and write that polyphony. My point of view, first person, third, my 'voice', is drawn from the texts, the pictures, films and oral histories I've examined. How do I do as Henry James prompts and capture their visual shock, their openness, and their 'truths'?

My initial approach to researching Vietnam was based on observation and pictures. I first visited the country in 1994. I hadn't travelled through much of Asia at that point, just Hong Kong and Sri Lanka. I went to Hanoi because a friend told me it was just like Paris; and France, I had decided by then, was a kind of spiritual home. I went with a camera acting as my amanuensis. It would write a Vietnam in photos, drawn from the colonial before the battle of Dien Bien Phu, before the Vietnam War, before the Fall of Saigon, before the fleeing Vietnamese of 1975, before Cabramatta and visits to eat Pho soup - a romantic French Vietnam to be recolonised in pictures and words.

Writers research in archives; we research ourselves, using storytelling and all the felt research that informs it to search for our origins, to paraphrase Roland Barthes in The Pleasure of the Text (1980). In so doing I made a number of choices about how I would shape my fictional narrative - the usual writerly ones about point of view, voice, pace and plot but also, significantly, the way I would used my fascination with colonialism to recolonise, as it were, the French in a similar way to how the French colonised Vietnam. I chose to write my story as a family narrative because so much of the colonial relies on the language of family relationships and the infantilising of the colonised, but also because I like to examine the way history resides in the domestic narrative. The kind of history I am interested in researching is mediated through the domestic life of photos and stories that become family myths. Regardless of whether I'm researching fiction or nonfiction, I am much more interested in the 
domestic details, and always have been. The grand narratives of war, of heroic struggle, of defeat and victory, are best seen from behind a lacecurtained window, I would argue, or understood in a letter from home read at a kitchen table.

This need for a grand/domestic juxtaposition - the awful fatality of war and its politics, the daily lives of ordinary people - is paramount in the way in which a civil war, for example, can be viewed more eloquently though a child's confusion about Tet flowers or a French family's dogged refusal to mix with the people in whose country they reside, than through the official history. For me, the domestic is also the domain of authorial distance, the 'removed' people who peep as though from panopticons, from behind the shutters, understanding far more than they're given credit for. I'm also drawn to emulate the fiction writers who examine the machinations of politicians from a distance, over a dry martini, under a ceiling fan.

This is how a novelist researches, isn't it - in observational mufti?

Is there any reason why a writer wouldn't apply such techniques to all their other research? What is the difference between the manner in which I researched and wrote about the 50-year anniversary of Dien Bien Phu in my novel and in my nonfiction?

In Hanoi I interviewed Vietnamese and French soldiers who participated in the battle as well as people who continued to live and work in Hanoi. The disastrous battle was fought thousands of kilometres away, and Mr Le Van Phuc, at the time an accountant at the Metropole Hotel, now a father of twelve and living in America, recalled for me the way in which the life of the hotel and its French clients proceeded as normal. As news of the French defeat reached the city, the wife of the French General, De Castries, became more inclined to stay, weeping, in her room but there were clusters of people on street corners and partaking of the French equivalent of high tea.

Two decades later, imagine my Vietnamese friends who were children at the time of Vietnam's war with America and her allies. During the bombing of the North, they fled to dugouts and in them experienced the minutiae of underground life - the smell of the soil, the surprising little shells and stones the ground often holds, a child's excursion into the earth's layers as the planes roared overhead. This seemed like such an exquisite metaphor for the way a writer researches that I included it, with the consent of my friend Le Quang Hau, in my novel.

Tiny details.

As a writer/researcher I can capture images of war in historically accurate descriptions such as those in General Giap's memoir of Dien Bien Phu, or the numerous French books about the battle I see in Paris's museums and libraries. Or do they reside in the magic of the French camps' names Eliane, Dominique, Claudine, Huguette - to enchant a French child for whom Hanoi will soon be a memory? Girls' pretty names for such a punishing loss. Am I talking now from my work as a fiction writer or a nonfiction writer and does it really matter?

\section{What actually happened is less important than what is felt to have happened. Is that right? (Fraser 2001: Preface)}

The right of the question posed by British oral historian, Ronald Fraser, who has written multi-voiced narratives about the 1968 student uprisings 
in Paris, the Spanish Civil War, and the Manor House at Amnersfield in England, is loaded with the correct, but it also carries with it a sense of the moral or just. How important is researched historical veracity? Who determines the truth in historical narratives, anyway? Who owns events those who participated in them, the people to whom they passed their memories, the researchers who probe them or those who lose themselves in them by imagining what it must have been like to live through such times? Fraser saw history as a multi-facetted prism. It is polyglot, its truths derive from different ways of seeing, feeling, recalling. And in it we rediscover the story told by George Du Maurier and the story-thief, Henry James.

Writers, I believe, are quite rightly compelled by a desire to capture James' affect - the ways in which history's infectious imagery vivifies a narrative. A bone sticking out of a ploughed field, a fragment of a B52 in Hanoi's army museum, the sadness that flits across an old general's face when he recalls the war, the letters about the car he'll buy as soon as a young 'nasho', a conscripted national service soldier, gets home to his country town, speak more to me of the horror of war than the words of strategists and generals who explain the bigger picture. For me, writing relies on locking one's eyes with the destabilising. It is a quality writers of fiction incorporate into their novels and stories; we call it historical or emotional depth or believable characters or 'felt' truths and are lauded for it if we get it right.

All of the arguments and examples I've presented here have derived from my research - from the books, journals, interviews, and archives - the expected research activities of the trained researcher. But they also have relied on the practices of the trained fiction writer I am, who stalks with a notepad, taking things down for later use. As a fiction writer I like to write before I research, as a nonfiction writer the reverse - but frankly, that's not always the case. I've absorbed too much cultural history through contemporary narratives not to start crafting my narrative before I start reading. And what I write, the tone, atmosphere, the observations and the narrative voice are drawn from these.

How do I separate the two approaches and do I need to? I can write fictocritically, I can write journalistically, I can fictionalise; all rely on research. I can also include my research practices in my narratives - where the character speaks of her time in libraries and archives - and in yet another way, or process this time, my research enters the story.

Research should always allow this interplay shouldn't it? Interrogating, picking, with the Fraser, the Marker, the Eliot questions always on the lips. And of course, there's Henry James.

Whose history are we observing and how do we catch its affect?

The Vietnamese-American journalist and fiction writer, Andrew Lam, wrote to an American friend:

I once was envious of you for your "history happened to others on TV" and you, who grew up where everyone else wanted to live - could always change channels ... Your immunity from history robs you of the awe and appreciation of seeing how its powerful flow and surge can change everything ... unappreciative of your own history, 
you are deprived of the marvels of the history of others. (Lam 2005: 43)

How will I give voice to those who stayed and those who left, who fought, protested, went under duress, who have been re-educated, and those who are working for a more prosperous Vietnam through tourism and business? How will I capture the old man who offered me his flower that day in Ho Chi Minh City and to whom I replied, you keep it, Uncle, this is your day? Or the French at my hotel, some of them not realising that this was a parade to mark the end of the American war? Or the teenage girls who go shopping in Vietnam's flash new supermarkets every Saturday afternoon, hand in hand? Or the young Australian tourists who flock to Vietnam, knowing nothing of its past and the young Vietnamese, two-thirds of them born after the war and just focussed on a happy, bright future?

What kind of narrative should my writing make of all of them?

Editors Doyle, Grey and Pierce use the word 'inconclusion' to answer such questions in their book Vietnam Days: Australia and the Impact of Vietnam (1991) which is perhaps where all questions of research and writing should retire. Australia's longest war, a country that talks to us still and in which we continue to locate ourselves. I can think of few countries in which the threads still weave and unweave themselves so potently. A tourist's delight in Vietnam's people and places. A protest rally outside Sydney Town Hall in which a Vietnamese gala is taking place. Australian soldiers returning to Phuc Thuy Province to set up an orphanage. Brochures published in Hanoi editing the language so it doesn't offend Vietnam's former enemies. Robert McNamara saying the war was a mistake. Vietnam veterans marching proudly on Anzac day. A lunch with visiting Vietnamese politicians in Glebe at which they agree that 'Viet Kieu' is a term highly offensive to many expats, and that they want publicly to acknowledge the role the overseas Vietnamese have played in Vietnam's economic development.

The best I can do is attempt to allow all these threads to inform a novel, a research monograph, any writing I do.

'Which narrative, which image of the Vietnam experience is the one that the community now wants to project?' Pierce, Gray and Doyle ask.

My research is predicated on the idea that through writers sharing the frustrations of putting words to paper, of imagining and recalling a time, a place, an atmosphere, by enabling the people we were and have become to enter our narratives, we will somehow come to some kind of response to the complex questions of our shared history.

And perhaps the response will be just another question and that will be enough.

\section{Works cited}

Barthes, Roland 1980 The pleasure of the text, trans. Richard Miller, Hill and Wang, New York Return to text

Doyle, Jeff, Jeffrey Grey and Peter Pierce (eds) 1991 Vietnam Days: Australia and the Impact of Vietnam, Penguin Books, Ringwood Return to text

Fraser, Ronald 2001 The Manor House at Amnersfield, 1933-1945, Thetford Press, Fyfe

Return to text 
James, Henry 1984 'On the Genesis of "The Real Thing"', in Ann Charters (ed) The Story about M/Ms Writer, St Martins, Bedford, 1233-42 Return to text

Lam, Andrew 2005 Perfume dreams: Reflections on the Vietnamese diaspora, Heyday Books, Berkeley Return to text

Dr Catherine Cole is a Senior Lecturer in Writing at the University of Technology, Sydney where she teaches writing. She has published novels, short fiction, poetry and nonfiction. She has been the recipient of an Asia Link Residency to Vietnam and the Keesing Studio in Paris. Her current research includes projects on the writers of Vietnam and the Asia-Pacific region as well as creativity and identity. This paper was presented at the the University of Sydney Writing Out seminars in Sydney and at the University of New England, Armidale in March and August 2006.

\section{TEXT}

Vol 10 No 2 October 2006

http://www.griffith.edu.au/school/art/text/

Editors: Nigel Krauth \& Jen Webb

Text@griffith.edu.au 